\title{
THE RULE OF LAW IN THE ATLANTIC COMMUNITY
}

\section{Christian A. Herter $\dagger$}

The eventual salvation of mankind will depend upon the orderly development throughout the world of common precepts implemented by some formal common institutions and upon a general acceptance of the Rule of Law in its simplest terms. The alternative is chaos as a result of the extraordinarily rapid development of communications and the vast political and scientific changes which have taken place in the last century.

I was somewhat impressed, with reference to this latter point, by a statistic which I came across recently: three percent of all the people who have ever lived on this planet are alive today; ninety percent of all the scientists who have ever lived are also alive today. These figures illustrate the rapid pace of population growth and development of a new scientific era. The velocity of change may be faster than existing political communities are able to cope with. The effective organization of society, therefore, has become increasingly urgent.

The post-war efforts to create regional communities may point up principles which can be applied on a larger scale to the international organization of society. For present purposes, I will mention only two regional communities and will dwell on only one. These are the Organization of American States (OAS) and the European Economic Community (EEC).

\section{The Organization of American States}

The Organization of American States was created shortly after World War II. Its charter ${ }^{1}$ is a very voluminous document, which has been several times amended and enlarged. However, the Organization has not lived up to expectations; institutionally it lacks methods of enforcement, and in practice its members have often been unable to reach agreement.

The Charter of the OAS in many ways reflects the feelings of Latin Americans on three vital matters. The first of these is pro-

$\dagger$ United States Ambassador and Envoy Plenipotentiary, Special Representative for Trade Negotiations.

1 Charter of the Organization of American States, April 30, 1948, [1951] 2 U.S.T. \& O.I.A. 2394, T.I.A.S. No. 2361. 
tection. The Charter is a mutually binding treaty between the signatories whereby they have pledged to come to each other's assistance in the event of a military attack by a nonsignatory. Secondly, the Charter takes account of Latin American concern with outside interference in their internal affairs. This concern is partially a result of the history of revolution in South America. It is also based on the history of United States intervention, particularly the use of Marines in times of crisis. The member states of the OAS feel very strongly that outside powers should never interfere with revolutions per se. Thirdly, the Charter deals with human rights. The signatories have been very vocal on this subject. However, despite their eloquence, they have not always fulfilled their high hopes with regard to human rights.

The future course of the regional arrangement outlined in the Charter of the OAS is uncertain. The recent events concerning Cuba may well affect the thinking of Latin American countries on the subject of ideological interference by a member state or an outside power. In Caracas, a number of the member states condemned Soviet infiltration of South America. I am optimistic, therefore, that the OAS will grow in effectiveness.

\section{The European Economic Community}

The European Economic Community, in my opinion, offers the greatest hope for the creation of an orderly world, a world in which there is common law with common institutions to enforce that law.

In discussing developments in Europe, one must go back a little in history. Before doing so, however, I would like to say a word about the current situation. There has been a great deal of speculation concerning the events of recent months, particularly General De Gaulle's publicly expressed attitude and the recent cessation of the Brussels' negotiations for British entry into the Market. Personally, I believe that the movement begun in 1948 has sufficient impetus to carry on regardless of individuals. Because the EEC offers the greatest hope of building the type of world we all want to see, setbacks, while inevitable, should not be permitted to become irrevocable.

\section{A. The Coal and Steel Community}

The history of the EEC begins prior to World War II, with serious French efforts to bring together the nations of Europe, particularly France and Germany. These early attempts were, of course, nullified by the intervention of Hitler and World War II. But after the war it was readily apparent that if Europe was to avoid a series of internal and self-destructive wars, a new social and political arrange- 
ment was mandatory. The feeling was that although the change would have to be far reaching, its origins would of necessity have to be humble.

The first concrete step was not taken until 1950. In that year, Belgium, Luxembourg, Holland, France, Germany, and Italy formed the European Coal and Steel Community. ${ }^{2}$ Messrs. Schuman, Monnet, and Adenatuer decided that if these countries could bring order into a functional and overlapping segment of their economies, they might well spark the growth of a much closer and larger economic partnership. It is interesting to note that this development took place only shortly after the birth of NATO, a military alliance of a type the world had never seen before. In addition to its military provisions, the NATO Treaty sought to encourage closer political and economic ties between its signatories.

The Coal and Steel Community dealt with matters which had been the subject of intense rivalry between Germany and France-coal and steel and the production of weapons which resulted therefrom. The Community was in effect a government of six nations dealing with only a segment of the problems of those nations. It was governed by a High Authority - an executive body of technical experts-, a council of ministers, a parliamentary body, and a court. The council of ministers could veto or approve decisions of the High Authority, but could not vacate judicial orders implementing the treaty creating the community. The parliamentary body had power only to recommend and discuss projects.

\section{B. Creation of the Common Market}

The Coal and Steel Community was so successful that the six members determined that the time had come to expand in the economic sphere. Their goal was to create a structure which would promote increased trade between them and which could eventually be transformed into a political entity of the first order.

It might be appropriate at this point to quote a statement by Winston Churchill made at the Hague in 1948, a time when the Coal and Steel Community was being conceived and the possibility of a United States of Europe explored. But it was also a time when governments were afraid to talk about these things themselves. Instead, they looked to private citizens and elder statesmen, by discussion in private conclaves and meetings, to clear the way for government action. In any such effort to pull sovereign nations together, the

2 Treaty Instituting the European Coal and Steel Community, April 18, 1951, 261 U.N.T.S. 140. 
question of sovereignty is a great bugaboo. As I interpret it, sovereignty is a democratic form of government in which power is yielded by the people in order to bring about a civilized order. Each law that is passed constitutes a decision by representatives to whom the people have delegated authority to make rules and regulations by which they can live together. The same is true in the international sphere of each treaty that is made. Nations, however, never relinquish sovereignty unless they feel that it will be for the greater good. $\mathrm{Mr}$. Churchill's statement is particularly appropriate on this subject. While many people made reference to sovereignty at that time, he was one of the few who did so frankly.

It is impossible to separate economics and defence from the general political structure. Mutual aid in the economic field and joint military defence must inevitably be accompanied step by step with a parallel policy of closer political unity. It is said with truth that this involves some sacrifice or merger of national sovereignty. But it is also possible and not less agreeable to regard it as the gradual assumption by all the nations concerned of the larger sovereignty which can alone protect their diverse and distinctive customs and characteristics and their national traditions all of which under totalitarian systems, whether Nazi, Fascist, or Communist, would certainly be blotted out forever. ${ }^{3}$

The document which resulted from the negotiations of 1957 was an extraordinary one, known as the Treaty of Rome. ${ }^{4}$ It has 247 articles, four large annexes, and more than nine protocols attached to it. Although the Treaty contains many of the elements of a constitution, it recognizes the need for organic development by specifically providing that certain matters which could not be resolved initially will be the subject of later discussion by the signatories.

\section{The Governmental Structure of the EEC}

\section{The Council, Foreign Ministers, and Legislature}

The governing bodies created by the Treaty are in many respects similar to those of the Coal and Steel Community. The Executive Council, sitting in Brussels, is made up of experts who are not supposed to represent any nation but rather the Community as a whole. While it cannot initiate action, the Council may make recommenda-

3 Address by Winston S. Churchill, Congress of Europe, May 7, 1948, in Europe UNITE 310, 312-13 (R. Churchill ed. 1950).

4 Treaty of Rome for the Establishment of the European Economic Community, March 25, 1957, 298 U.N.T.S. 14. 
tions to the Foreign Ministers of the six member nations. It should also be pointed out that the Executive Council, in addition to proposing steps to be taken, has created special committees to study certain problems and recommend a course of action. The staff members of these committees are now referred to in Europe as Eurocrats.

The Ministers, in turn, may reject or approve recommendations of the Council but may not initiate proposals of their own. Thus, the six Foreign Ministers in effect have the power of veto. As originally conceived, the EEC was to mature in three stages. It is presently in the second. The third stage is scheduled for 1966. At that time, the Foreign Ministers by a two-thirds vote will be able to bind all six nations. Under this system, Germany, France, and Italy will have four votes, Holland and Belgium two, and Luxembourg, one. The parliamentary body of the EEC is very similar to that of the Coal and Steel Community. However, it has the additional power to impeach the professional technicians who make up the Executive Council. But to do so, it must impeach them as a body.

\section{The Court}

The Court of the EEC demonstrates, perhaps better than any other institution, the scope of the regional community structure created by the Treaty of Rome. The Court has a great deal of power: the member states have agreed to enforce money judgments of the Court against national enterprises and citizens; in addition, they have bound themselves to accept the findings of the Court in controversies between themselves.

Not being a lawyer myself, I would like to refer to Professor Eric Stein's brief summary of the Court's jurisdiction:

The Court's jurisdiction is varied and in some respects unique, defying categorization. For the purposes of illustration and at the admitted risk of drawing loose analogies, one might say that the Court's jurisdiction is analogous to the federal jurisdiction of the United States Supreme Court, to the "administrative" jurisdiction of the French Counseil d'Etat or the German Bundesverwaltungsgericht, and is at the same time a "civil" jurisdiction, and in a sense the jurisdiction of an international tribunal.

The Court's jurisdiction is similar to that of a federal court in regard to controversies between Member States concerning the application of the Treaty-controversies similar to those between States of the Union which the U.S. Supreme Court is asked to resolve under the Federal Constitution or statutes. The Court's jurisdiction may also be viewed as 
"federal" in disputes between Member States and Community institutions, between the institutions themselves, and in cases where the Court decides whether proposed international agreements to be concluded by the Community are compatible with the Treaty. Finally, one might mention in this category the jurisdiction of the Court to rule on questions arising in national judicial proceedings which concern interpretation of the Treaty and the validity and interpretation of the acts of the institutions. National courts of last resort are bound to refer these "federal" questions to the Court for binding determination. This obligation on the part of the national courts has been substantially strengthened in the Rome Treaty as compared with the Coal-Steel Treaty.

The Court's jurisdiction is "administrative" ("public municipal") where it affords legal redress to individuals and enterprises praying that administrative acts of the Community institutions be annulled. The right of access of private parties to the Court-their governments need not interveneis a necessary corollary to the power of the institutions to act with direct effect upon these parties. This right marks a radical departure from the conventional international tribunal, enables the Court to exercise its powers of control over the institutions and adds to the "public municipal" characteristics of the Communities.

The "civil" jurisdiction (in the common law sense) of the Court extends to cases in tort against the Community and on contracts to which the Community is a party. In contract cases the jurisdiction of the Court must have been stipulated.

Finally, the jurisdiction of the Court may be said to resemble that of an international tribunal where the Court determines controversies between the Community and a nonmember state arising out of an international agreement or possibly out of a contract in which the parties stipulated such jurisdiction.

National authorities in the Member States are bound to execute money judgments of the Court against individuals and enterprises. ${ }^{5}$

The Court has from its inception been very busy, but there have been few complaints about its decisions. It is encouraging that the member states have shown such confidence in the Court, for a judicial body is a basic institution in the creation and maintenance of legal order in any level of community.

5 Stein, The Neze Irstitutions, in 1 AMERICAN ENTERPRISE IN THE EUROpEAN Common Market-A Legal Proftue 33, 70-71 (Stein \& Nicholson ed. 1960). 


\section{Other Organizations in the European Community}

At the time of the Marshall Plan, there was created in Europe an organization known as the Organization for European Economic Cooperation (OEEC). One of the primary purposes of this body was to break down continental trade barriers in order to foster the post-war economic recovery of Europe. However, it did much more than that. The OEEC was instrumental in allocating American aid among the nations of Europe, thus relieving the United States of a very difficult task. The OEEC was composed of very able experts to whom, in my opinion, must go much of the credit for the success of the Marshall Plan.

At least two other European regional organizations deserve mention at this point: the General Agreement on Tariffs and Trade (GATT) and the Organization of Economic Cooperation and Development (OECD). This latter body can only make recommendations, but within this limited framework, it has been extremely effective.

\section{The Future Development of the European Regional Community}

A little over one year ago, an extraordinary group of people met at a convention in Paris. This convention was the result of a joint resolution of Congress, ${ }^{6}$ signed by President Eisenhower. By the terms of the resolution, a Citizens Committee, composed of twenty individuals equally representing the two major political parties in the United States, was established for the purpose of encouraging member nations of NATO to set up similar groups which would meet together and make recommendations for strengthening NATO ties, particularly in the economic and political sphere. I was appointed to the American delegation and became co-chairman with Mr. Clayton of Texas. Eventually, I was elected chairman of the international convention held in Paris.

The convention was an unusual one because the delegates represented no one. We simply sat around a conference table, hoping to devise helpful recommendations for promoting closer collaboration not only between NATO members but within the entire Atlantic Community. The discussions dealt with political and economic matters; we did not deal with military issues because of the serious disagreement that continues to exist among NATO nations over the control of atomic weapons.

674 Stat. 818 (1960) 
The convention began with this Preamble:

We the citizen delegates to the Atlantic Convention of NATO nations meeting in Paris January 8 to 20, 1962, are convinced that our survival as free men and the possibility of progress of all men demand the creation of a true Atlantic Community within the next decade and therefore submit this declaration of our convictions.

The convention made several institutional and many cultural suggestions; the former are of primary interest to us here. First, we recommended that a High Authority be created, headed by a chairman to be chosen by rotation from the member states. This Authority would have the power to bind participating nations to a common policy on certain military and economic matters, since an understanding in these areas is a requisite to any eventual political unity of the Atlantic Community. In addition, the convention recommended the creation of a regional legislature which would initially be limited to the discussion of proposals as are the regional parliaments of the Coal and Steel Community and of the EEC. At a later date it might be given more extensive powers. Another recommendation dealt with an Atlantic Court which would adjudicate disputes arising under the document or treaty creating this Atlantic Community.

In essence, the community which we recommended would extend beyond NATO and the EEC; it would be an outward-looking commun-. ity, not a rich man's club. Hopefully, this community would make it possible for the industrial powers to give greater aid to the less developed nations as well as to deter Communist aggression.

Any legal order cannot, of course, be created over night. It must be a slow, even tedious process. I would recommend, however, that it be pursued constantly. Government commissions should be established to give further study to the proposals of the Paris convention. Only as a result of such efforts may we succeed in creating a world in which the majority of nations, and eventually all of them, live together under the Rule of Law. 